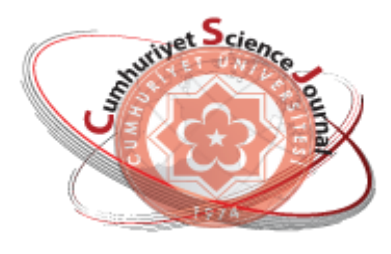

e-ISSN: $2587-246 X$

ISSN: $2587-2680$

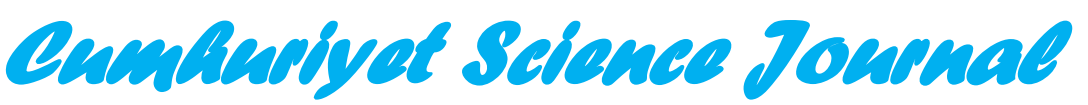

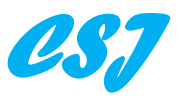

Cumhuriyet Sci. J., Vol.40-3 (2019) 742-752

\title{
Investigation of The Gamma Ray Shielding Behaviour of (90-x)TeO2- xMoO3 - 10ZnO Glass System Using Geant4 Simulation Code and WinXCOM Database
}

\author{
Ali AŞKIN ${ }^{I^{*}}$ (D), Murat DAL $L^{2}$ \\ ${ }^{1}$ Munzur University, Faculty of Engineering, Mechatronic Engineering Department, Tunceli, TURKEY \\ ${ }^{2}$ Munzur University, Faculty of Engineering, Civil Engineering Department, Tunceli, TURKEY
}

\begin{abstract}
In this study, mass attenuation coefficients $(\mu \mathrm{m})$, transmission fractions (T), mean free path (MFP) and half value layer (HVL) of the (90-x)TeO2-xMoO3-10ZnO glass system ( $\mathrm{x}=10,20$ and $30 \mathrm{~mol} \%)$ were calculated at the gamma ray photon energies of $356 \mathrm{keV}, 662 \mathrm{keV}, 1173 \mathrm{keV}$ and $1330 \mathrm{keV}$. Shielding parameters of the glass system were calculated from the Monte Carlo simulations carried out with the Geant4 model of a high purity germanium (HPGe) detector and from the WinXCOM database software. The used Geant 4 model was validated by comparing the experimentally determined mass attenuation values of the $\mathrm{PbO}-$ $\mathrm{BaO}-\mathrm{B} 2 \mathrm{O} 3$ glass system to the values calculated with Geant 4 . The findings of the present study reveals that the glass system containing $10 \% \mathrm{~mol} \mathrm{MoO} 3$ exhibits better photon shielding performance compared to the glass with $30 \%$ mol of $\mathrm{MoO} 3$ due to the higher amount of $\mathrm{TeO} 2$ existed in its chemical formula.
\end{abstract}

Keywords: Geant 4 , Simulation, Glass, Photon attenuation.

\section{(90-x)TeO2 - xMoO3 - 10ZnO Cam Sisteminin Gama Işını Zırhlama Özelliklerinin Geant4 Simulasyon Kodu ve WinXCOM Veri Tabanı Kullanılarak Araştırılması}

\footnotetext{
Özet. $\mathrm{Bu}$ çalışmada 90-x)TeO2-xMoO3-10ZnO cam sisteminin (x=10, 20 and $30 \%$ mol) kütle zayıflatma katsayıları $(\mu \mathrm{m})$, geçirgenlik oranları (T), ortalama serbest yol (MFP) ve yarı değer (HVL) parametreleri 356 $\mathrm{keV}, 662 \mathrm{keV}, 1173 \mathrm{keV}$ and $1330 \mathrm{keV}$ gama foton enerjilerinde hesaplanmıştır. Zırhlama parametrelerini yüksek saflıkta germanium (HPGe) dedektörünün Geant4 modeli ile gerçekleştirilen Monte Carlo simulasyonları ve WinXCOM veri tabanı kullanılarak hesaplanmıştır. Geant4 modelinin geçerliliği $\mathrm{PbO}-$ $\mathrm{BaO}-\mathrm{B} 2 \mathrm{O} 3$ cam sistemi için deneysel olarak bulunan kütle zayıflatma katsayayıları Geant4 ile elde edilen sonuçlarla karşılaştırılarak sağlanmıştır. Bu çalışmanın sonuçları kimyasal formülünde yüksek oranda $\mathrm{TeO} 2$ bulunmasından dolay $\% 10 \mathrm{~mol} \mathrm{MoO} 3$ içeren cam sisteminin radyayon zırhlama özelliklerinin $\% 30 \mathrm{~mol} \mathrm{MoO} 3$ cama göre daha iyi olduğunu göstermiştir.
}

Anahtar Kelimeler: Geant4, Simülasyon, Cam, Foton zayıflatma..

\section{INTRODUCTION}

Investigation of the radiation shielding properties of materials is an increasing interest for researchers due to the wide use of radioactive isotopes in diverse fields, such as nuclear power plants, radiology and radiotherapy departments of hospitals, nuclear research and accelerator centers, agriculture, oil plants and archeology. Therefore, determination and knowledge of the radiation shielding properties of the materials used in these 
kind of places are of crucial importance to protect humans against the hazardous effects of the ionizing radiation. Gamma rays are one of the more penetrating radiation type and materials with high density and high atomic number are needed for their effective shielding. Lead is known as the best gamma ray attenuating material. Whereas, weight, price and toxicity of lead make it unpractical and uneconomical for the shielding of large areas. Recently, radiation shielding properties of different natural or synthetically produced materials, such as concrete, sand, cement, bricks, tiles, glasses, clay materials, polymers and alloys has been studied by different researchers $[1,8]$.

Having the advantages of optical transparency and easy preparation and production make the glasses attractive for the researchers to investigate and explore their shielding properties. Numerous studies reported that glasses are promising materials when used as gamma attenuator [9,11]. Because of this, synthesis of new glass systems have been made by several groups in order to improve their shielding potential. The gamma ray attenuation characteristics of the newly synthesized glasses have been determined either by using the experimental techniques or by using the Monte Carlo simulation codes.

Six glass pieces with composition of $\mathrm{PbO}-\mathrm{Li} 2 \mathrm{O}-$ $\mathrm{B} 2 \mathrm{O} 3$ were prepared by using the melt quenching technique and the shielding properties of the samples were experimentally determined at four different gamma ray energies. The results of the study showed that the increase of $\mathrm{PbO}$ content increases the shielding efficiency [12]. The effect of $\mathrm{La} 2 \mathrm{O} 3$ on the radiation attenuation characteristics of the lanthanum calcium silicoborate glasses is experimentally measured at eight different photon energies between $224 \mathrm{keV}$ and $662 \mathrm{keV}$. It was reported that the increase of the $\mathrm{La} 2 \mathrm{O} 3$ concentration results in an increase the shielding ability of the lanthanum calcium silicoborate glasses [13]. Five different samples of Bi2O3-BaO-B2O3-Na2O quaternary glass system were produced and their structural and gamma ray shielding features were investigated experimentally by Dogra et al. [14]. It was reported that the samples have higher mass attenuation and lower half value layer compared to barite concrete at $662 \mathrm{keV}$. In addition to the experimental techniques, Monte Carlo simulations can be employed to study the radiation interaction parameters of the materials especially in the absence of the expensive experimental equipments or in the absence of the fabricated samples. Modelling of an experimental set-up consisting of a detector, a gamma ray source and an attenuator and performing the measurements in the computer environment provide an ease of use and save time. Shielding properties of $80 \mathrm{TeO} 2-5 \mathrm{TiO} 2-(15-$ $\mathrm{x}) \mathrm{WO}$ - $\mathrm{xAnOm}$ glasses were investigated by using MCNP5 code and WinXCOM. The results of this study revealed that using of $5 \mathrm{Er} 2 \mathrm{O} 3$ in the places of xAnOm significantly increases gamma ray and neutron shielding behavior [15]. Gamma and neutron shielding capabilities of $20 \mathrm{BaO} / \mathrm{SrO}$ (x)Bi2O3- (80-x)B2O3, where $\mathrm{x}$ value was changed between 10 and $60 \mathrm{~mol}$, glasses has been investigated computationally by using the MCNP5 code and WinXCOM. It was published that the addition of $\mathrm{Bi} 2 \mathrm{O} 3$ increases the shielding effectiveness of the glass system [16]. 
In this study, the complete geometry of a high purity germanium (HPGe) spectrometer produced by Canberra semiconductors was coded into Geant 4 in order to determine the mass attenuation coefficients $(\mu \mathrm{m})$, transmission fractions $(\mathrm{T})$, half value layer (HVL) and mean free path (MFP) of the

\section{MATERIALS AND METHODS}

\subsection{Theoretical Background}

Mass attenuation coefficient is a substantial parameter defining the penetration and diffusion of gamma ray photons within the material. BeerLambert's law as given by equation (1) was used to calculate the mass attenuation coefficients of the selected glass system.

$$
\mathrm{I}=\mathrm{I}_{0} \cdot \mathrm{e}^{-\mu \cdot \mathrm{x}}
$$

Where $I$ and $I_{0}$ are the transmitted and incident photon intensities respectively, $\mathrm{x}(\mathrm{cm})$ is the thickness of the material and $\mu\left(\mathrm{cm}^{-1}\right)$ is the linear attenuation coefficient of the sample. In order to measure the incident photon intesity, Monte Carlo simulations were performed at each selected energy without the sample placed between the source and the detector. Simulations were then repeated with the sample placed between the source and the detector to obtain the attenuated photon intensities. The logarithm of transmission $\left[\ln \left(\mathrm{I} / \mathrm{I}_{0}\right)\right]$ is plotted versus sample thickness and the slope of linear fit to these data points results in linear attenuation coefficient. The mass attenuation coefficient $\left(\mu_{\mathrm{m}}\right)$ is widely used for the calculation of photon transmission and energy deposition within a material. $\mu_{\mathrm{m}}$ of any material is then calculated by dividing the linear attenuation coefficient with the density of sample:
(90-x)TeO2-xMoO3-10ZnO glass system from the Monte Carlo simulations. In addition to the Monte Carlo simulations, $\mu \mathrm{m}$ values of the selected glass system have been also determined using the WinXCOM database and compared to the results from Geant4.

$$
\mu_{\mathrm{m}}=\mu / \rho
$$

The transmission fraction, $\mathrm{T}$, is the fraction of the transmitted photon intensity (I) to the incident photon intensity $\left(\mathrm{I}_{0}\right)$. Plotting of $\mathrm{T}$ versus $\mathrm{x}$ can be used to estimate the decrease in the photon intensity with respect to the material thickness. This parameter is calculated as:

$$
\mathrm{T}=\mathrm{I} / \mathrm{I}_{0}
$$

The half-value layer (HVL) is the thickness of a material needed to reduce the intensity of the incident radiation by one-half. Its dependence to the linear attenuation coefficient, $\mu$, is defined by the Eq. (4)

$$
\mathrm{HVL}=\ln (2) / \mu
$$

The mean free path (MFP) defined as the average distance travelled by a photon between two successive interactions is equal to the reciprocal of the linear attenuation coefficient as given in next equation:

$$
\mathrm{MFP}=1 / \mu
$$

\subsection{Geant4 Model of HPGe Detector}

Geant 4 is a Monte Carlo simulation toolkit is based on the object oriented $\mathrm{C}++$ programming and used for the modeling of the detectors for the high energy, nuclear, accelerator, medical and low 
energy physics applications. The Geant4 kernel manages runs, events and tracking of passage of particle through matter. It allows users to simulate all aspects of an experimental set up such as geometry of detector, primary particle generation of events, types of particles and physics processes such as electromagnetic, hadronic and decay physics that manages particle interactions [17].

In this work, the simulated detector geometry is based on the HPGe detector produced by the Canberra semiconductors. The core of the detector consists of a $2.2 \mathrm{~kg}$ HPGe crystal installed as an ionization detector. The crystal is $82 \mathrm{~mm}$ in diameter and $81.5 \mathrm{~mm}$ in height. The core cavity of crystal is $10.5 \mathrm{~mm}$ in diameter and $62.5 \mathrm{~mm}$ in height. The detector has a $1 \mathrm{~mm}$ thick copper endcap window placed $6.3 \mathrm{~mm}$ from the top of germanium crystal. The thickness of the crystal dead layer is $0.8 \mathrm{~mm}$. Fig. 1 shows the Geant 4 model of the HPGe detector geometry.
As shown in Fig. 2, the detector and the gamma ray source were surrounded with lead shields. A cavity with $3 \mathrm{~mm}$ in diameter and $50 \mathrm{~mm}$ in height is defined at the center of the both shields to create a narrow beam in order both to ensure that the BeerLambert's law is valid and to minimize the variance and systematic errors. The chemical composition in mol\% and weight fractions of elemental composition along with the densities of (90x) $\mathrm{TeO}_{2}-\mathrm{xMoO}_{3}-10 \mathrm{ZnO}$ (shortly referred as TMZ) glass system has been coded into Geant4 according to the values as given in Table 1 [18]. During the simulations, the thickness of the glass sample was varied from $1 \mathrm{~cm}$ up to $5 \mathrm{~cm}$ with $1 \mathrm{~cm}$ increment and simulations were repeated for the new thickness. The glass sample was placed between the source and the detector as an attenuator and the mass attenuation values of the TMZ glass systems have been reported at the gamma ray energies of $356 \mathrm{keV}\left({ }^{133} \mathrm{Ba}\right), 662 \mathrm{keV}$ $\left({ }^{137} \mathrm{Cs}\right), 1173 \mathrm{keV}\left({ }^{60} \mathrm{Co}\right)$ and $1330 \mathrm{keV}\left({ }^{60} \mathrm{Co}\right)$.

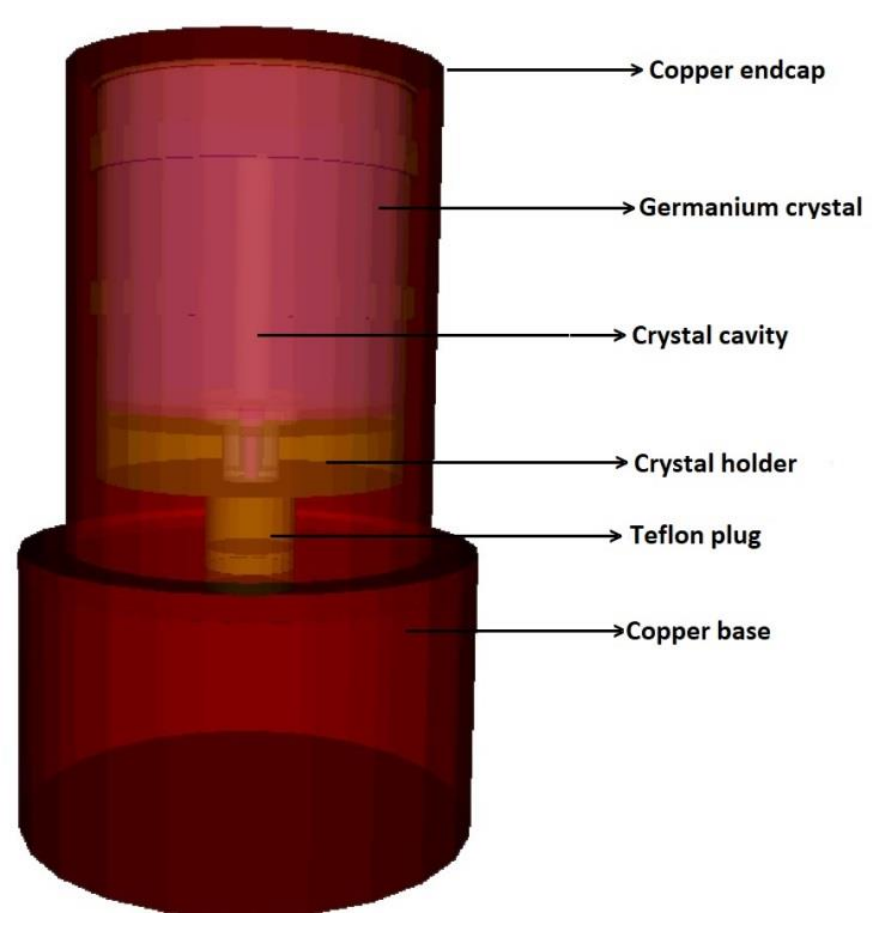

Figure 1. Geant4 model of the HPGe detector. 


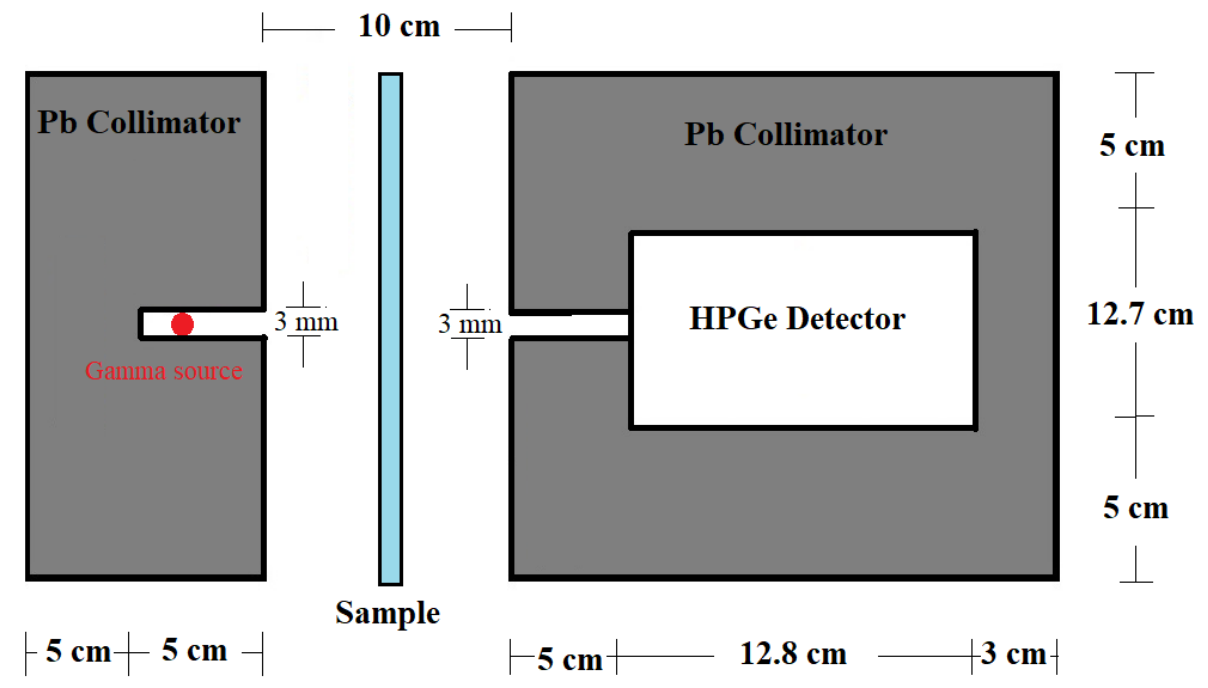

Figure 2. Schematic of the Geant 4 set-up used to perform Monte Carlo simulations

Table 1. The chemical composition and density of $(90-\mathrm{x}) \mathrm{TeO}_{2}-\mathrm{xMoO}_{3}-10 \mathrm{ZnO}$ glass system

\begin{tabular}{ccccccc}
\hline Code & Glass sample in mol (\%) & \multicolumn{3}{c}{ Mass fraction (\%) } & \multicolumn{2}{c}{$\begin{array}{c}\text { Density } \\
\text { (gr/cm }\end{array}$} \\
\cline { 3 - 6 } & & $\mathrm{Te}$ & $\mathrm{O}$ & $\mathrm{Mo}$ & $\mathrm{Zn}$ & \\
TMZ10 & $80 \mathrm{TeO}_{2}-10 \mathrm{MoO}_{3}-10 \mathrm{ZnO}$ & 67.9 & 21.3 & 6.45 & 4.35 & 5.103 \\
TMZ20 & $70 \mathrm{TeO}_{2}-20 \mathrm{MoO}_{3}-10 \mathrm{ZnO}$ & 60.0 & 22.6 & 13.0 & 4.4 & 5.066 \\
TMZ30 & $60 \mathrm{TeO}_{2}-30 \mathrm{MoO}_{3}-10 \mathrm{ZnO}$ & 52.0 & 24.0 & 19.56 & 4.44 & 4.976 \\
\hline
\end{tabular}

\subsection{WinXCOM Database Software}

WinXCOM database can also be used to calculate $\mu_{\mathrm{m}}$ values of any material and this software does not require any experimental setup [19]. Calculation of the $\mu_{\mathrm{m}}$ values is based on the mixture rule given by the following equation.

$$
\left(\mu_{m}\right)_{\text {glass }}=\sum_{\mathrm{i}}^{\mathrm{n}} \mathrm{w}_{\mathrm{i}}\left(\mu_{\mathrm{m}}\right)_{\mathrm{i}}
$$

Where $w_{i}$ and $\left(\mu_{m}\right)_{i}$ are the weight fraction and mass attenuation coefficient of the $i^{\text {th }}$ element respectively.

\section{RESULTS AND DISCUSSION}

\subsection{Validation of the Geant 4 model}

Prior starting the Monte Carlo simulations for the $(90-\mathrm{x}) \mathrm{TeO}_{2}-\mathrm{xMoO}_{3}-10 \mathrm{ZnO}$ glass system, the validty of the Geant 4 model of was proven by comparing the experimentally obtained mass attenuation values of $20 \mathrm{MoO}_{3}-\mathrm{xBi}_{2} \mathrm{O}_{3}-(80-\mathrm{x}) \mathrm{B}_{2} \mathrm{O}_{3}$ glasses $(x=10,20,30,40 \mathrm{~mol} \%)$ [20] to the Geant 4 based simulation results. The findings from the both studies are shown in Table 2 . The relative difference of the experimental and Geant 4 results vary between $0.7 \%-12.4 \%$. From the validation of the Geant 4 model, we are confident about the reliability of the values determined as the shielding parameters of $(90-\mathrm{x}) \mathrm{TeO}_{2}-\mathrm{xMoO}_{3}-10 \mathrm{ZnO}$ glasses and any other glass system which has not been investigated previously. 
Table 2. Mass attenuation coefficients of $\mathrm{MoO}_{3}-\mathrm{Bi}_{2} \mathrm{O}_{3}-\mathrm{B}_{2} \mathrm{O}_{3}(\mathrm{MoBiB})$ glasses calculated with Geant 4 and comparison to experimental data [20] for the validation of the Geant4 model.

\begin{tabular}{|c|c|c|c|c|c|c|c|c|}
\hline \multirow{2}{*}{$\begin{array}{l}\text { Glass } \\
\text { sample } \\
\end{array}$} & \multicolumn{2}{|c|}{$356 \mathrm{keV}$} & \multicolumn{2}{|c|}{$662 \mathrm{keV}$} & \multicolumn{2}{|c|}{$1173 \mathrm{keV}$} & \multicolumn{2}{|c|}{$1330 \mathrm{keV}$} \\
\hline & Geant4 & Exp. & Geant4 & Exp. & Geant4 & Exp. & Geant4 & Exp. \\
\hline MoBiB10 & $\begin{array}{c}0.2402 \\
0.0092\end{array}$ & $\begin{array}{c}0.2136 \pm \\
0.0128\end{array}$ & $\begin{array}{c}0.1029 \pm \\
0.0052\end{array}$ & $\begin{array}{c}0.0977 \pm \\
0.0048\end{array}$ & $\begin{array}{c}0.0657 \pm \\
0.0033\end{array}$ & $\begin{array}{c}0.0594 \pm \\
0.0071\end{array}$ & $\begin{array}{c}0.0512 \pm \\
0.0053\end{array}$ & $\begin{array}{c}0.0549 \pm \\
0.0028\end{array}$ \\
\hline MoBiB20 & $\begin{array}{c}0.2269 \pm \\
0.0098\end{array}$ & $\begin{array}{c}0.2201 \pm \\
0.00134\end{array}$ & $\begin{array}{c}0.1055 \pm \\
0.0046\end{array}$ & $\begin{array}{c}0.0986 \pm \\
0.0059\end{array}$ & $\begin{array}{c}0.0607 \pm \\
0.0050\end{array}$ & $\begin{array}{c}0.0603 \pm \\
0.0029\end{array}$ & $\begin{array}{c}0.0518 \pm \\
0.0050\end{array}$ & $\begin{array}{c}0.0554 \pm \\
0.0029\end{array}$ \\
\hline MoBiB30 & $\begin{array}{c}0.2354 \pm \\
0.012\end{array}$ & $\begin{array}{c}0.2234 \pm \\
0.0136\end{array}$ & $\begin{array}{c}0.1078 \pm \\
0.0050\end{array}$ & $\begin{array}{c}0.0996 \pm \\
0.050\end{array}$ & $\begin{array}{c}0.0599 \pm \\
0.0046\end{array}$ & $\begin{array}{c}0.0605 \pm \\
0.0029\end{array}$ & $\begin{array}{c}0.0581 \pm \\
0.0044\end{array}$ & $\begin{array}{c}0.0555 \pm \\
0.0029\end{array}$ \\
\hline MoBiB40 & $\begin{array}{c}0.2434 \pm \\
0.0080\end{array}$ & $\begin{array}{c}0.2302 \pm \\
0.0138\end{array}$ & $\begin{array}{c}0.0973 \pm \\
0.0046\end{array}$ & $\begin{array}{c}0.1011 \pm \\
0.051\end{array}$ & $\begin{array}{c}0.0579 \pm \\
0.0039\end{array}$ & $\begin{array}{c}0.0610 \pm \\
0.0030\end{array}$ & $\begin{array}{c}0.0513 \pm \\
0.0042\end{array}$ & $\begin{array}{c}0.0556 \pm \\
0.0029\end{array}$ \\
\hline
\end{tabular}

\subsection{Photon Shielding Behavior of $\mathrm{TeO}_{2}-\mathrm{MoO}_{3}-\mathrm{ZnO}$ Glass System}

The Geant 4 and WinXCOM results of $\mu_{\mathrm{m}}$ values for the $(90-\mathrm{x}) \mathrm{TeO}_{2}-\mathrm{xMoO}_{3}-10 \mathrm{ZnO}$ glass ternary $(\mathrm{x}=$ 10, 20, $30 \mathrm{~mol} \%$ ) are given in Table 3. The relative differences (RD\%) between the results from the both toolkits were calculated by using the following formula;

$$
\mathrm{RD}(\%)=\frac{\mathrm{R}_{\mathrm{G}}-\mathrm{R}_{\mathrm{W}}}{\mathrm{R}_{\mathrm{W}}} \times 100
$$

where $\mathrm{R}_{\mathrm{G}}$ and $\mathrm{R}_{\mathrm{W}}$ is the results from Geant4 and WinXCOM respectively.

As can be seen from the results presented in Table 3, the relative difference (RD) varies between $0.8 \%$ and $4.1 \%$ and the results from Geant 4 and WinXCOM are in agreement. Furthermore, it is observed that $\mu_{\mathrm{m}}$ decreases with the increasing photon energy. This trend in $\mu_{\mathrm{m}}$ is expected since the high energy photons have more penetration and diffusion ability within materials. Furthermore, in order to estimate the mass attenuation values at the photon energies which were not simulated, a four parameter $(\mathrm{p} 0, \mathrm{p} 1$, $\mathrm{p} 2, \mathrm{p} 3)$ exponential fit in the form of $\mu_{\mathrm{m}}=\mathrm{p} 0+\mathrm{p} 1 \cdot \exp (\mathrm{p} 2+\mathrm{p} 3 \cdot \mathrm{E})$ has been applied to the mass attenuation data calculated for all TMZ glass samples to obtain an equation to reproduce the mass attenuation coefficients at any desired energy within the range between 356 and $1330 \mathrm{keV}$. As shown in Table 4, the mass attenuation values calculated from the best fitted equations at the photon energies of $427.9 \mathrm{keV}$ $\left({ }^{125} \mathrm{Sb}\right),\left({ }^{134} \mathrm{Cs}\right), 834,8 \mathrm{keV}\left({ }^{54} \mathrm{Mn}\right), 1274.6 \mathrm{keV}\left({ }^{22} \mathrm{Na}\right)$ are in agreement with the results calculated using Geant4. It can therefore be concluded that these equations are reliable to calculate the mass attenuation of TMZ glass samples at any desired energy between 356 and $1330 \mathrm{keV}$.

Table 3: Comparison of mass attenuation coefficients $\left(\mathrm{cm}^{2} / \mathrm{g}\right)$ of the $\mathrm{TeO}_{2}-\mathrm{MoO}_{3}-\mathrm{ZnO}$ (TMZ) glass ternary obtained using Geant4 simulations and WinXCOM

\begin{tabular}{|c|c|c|c|c|c|c|c|c|c|c|c|c|}
\hline \multirow{2}{*}{$\begin{array}{l}\text { Glass } \\
\text { Sample }\end{array}$} & \multicolumn{2}{|c|}{$356 \mathrm{keV}$} & \multirow{2}{*}{$\begin{array}{c}\text { RD } \\
\%\end{array}$} & \multicolumn{2}{|c|}{$662 \mathrm{keV}$} & \multirow{2}{*}{$\begin{array}{c}\text { RD } \\
\%\end{array}$} & \multicolumn{2}{|c|}{$1173 \mathrm{keV}$} & \multirow{2}{*}{$\begin{array}{c}\text { RD } \\
\%\end{array}$} & \multicolumn{2}{|c|}{$1330 \mathrm{keV}$} & \multirow{2}{*}{$\begin{array}{c}\text { RD } \\
\%\end{array}$} \\
\hline & Geant4 & $\begin{array}{c}\mathrm{XCO} \\
\mathbf{M}\end{array}$ & & $\begin{array}{c}\text { Geant } \\
4\end{array}$ & $\begin{array}{c}\mathrm{XCO} \\
\mathbf{M}\end{array}$ & & $\begin{array}{c}\text { Geant } \\
4\end{array}$ & $\begin{array}{c}\mathrm{XCO} \\
\mathbf{M}\end{array}$ & & $\begin{array}{c}\text { Geant } \\
4\end{array}$ & $\begin{array}{c}\mathrm{XCO} \\
\mathbf{M}\end{array}$ & \\
\hline TMZ10 & $\begin{array}{l}0.120 \\
\pm 0.003\end{array}$ & 0.123 & 2.4 & $\begin{array}{l}0.0763 \\
\pm 0.006\end{array}$ & 0.0750 & 1.7 & $\begin{array}{l}0.0520 \\
\pm 0.005\end{array}$ & 0.0533 & 2.4 & $\begin{array}{l}0.0487 \\
\pm 0.004\end{array}$ & 0.0497 & 2.0 \\
\hline TMZ20 & $\begin{array}{l}0.123 \\
\pm 0.004\end{array}$ & 0.122 & 0.8 & $\begin{array}{l}0.0744 \\
\pm 0.004\end{array}$ & 0.0750 & 0.8 & $\begin{array}{l}0.0524 \\
\pm 0.006\end{array}$ & 0.0535 & 2.0 & $\begin{array}{l}0.0491 \\
\pm 0.005\end{array}$ & 0.0500 & 1.8 \\
\hline TMZ30 & $\begin{array}{l}0.125 \\
\pm 0.003\end{array}$ & 0.120 & 4.1 & $\begin{array}{l}0.0740 \\
\pm 0.004\end{array}$ & 0.0749 & 1.2 & $\begin{array}{l}0.0527 \\
\pm 0.005\end{array}$ & 0.0537 & 1.8 & $\begin{array}{l}0.0497 \\
\pm 0.005\end{array}$ & 0.0502 & 1.0 \\
\hline
\end{tabular}


Table 4. Best fitted equations for estimation of mass attenuation and comparison to Geant 4 results.

\begin{tabular}{cccccc}
\hline \multirow{2}{*}{$\begin{array}{c}\text { Glass } \\
\text { Sample }\end{array}$} & Best Fitted Equation & Energy $(\mathrm{keV})$ & \multicolumn{2}{c}{$\begin{array}{c}\text { Mass Attenuation } \\
\text { Coefficient }\left(\mathrm{cm}^{2} / \mathrm{g}\right)\end{array}$} & \begin{tabular}{c} 
Percentage \\
\cline { 3 - 5 }
\end{tabular} \\
\cline { 3 - 5 } Difference & Fitted & Geant 4 & Equation \\
TMZ10 & $\mu_{\mathrm{m}}=0.0437+0.0939 \cdot \exp (0.777-0.00276 \cdot \mathrm{E})$ & $427.9\left({ }^{125} \mathrm{SB}\right)$ & 0.106 & 0.110 & 3.6 \\
TMZ20 & $\mu_{\mathrm{m}}=0.0460+0.214 \cdot \exp (0.125-0.00324 \cdot \mathrm{E})$ & $834.8\left({ }^{54} \mathrm{Mn}\right)$ & 0.0622 & 0.0628 & 0.9 \\
TMZ30 & $\mu_{\mathrm{m}}=0.0475+0.235 \cdot \exp (0.144-0.00353 \cdot \mathrm{E})$ & $1274.6\left({ }^{22} \mathrm{Na}\right)$ & 0.0505 & 0.0499 & 1.2 \\
\hline
\end{tabular}

Fig. 3 shows the plot of the transmission values of TMZ glasses with respect to the glass thickness at the photon energies of $356 \mathrm{keV}, 662 \mathrm{keV}, 1173 \mathrm{keV}$ and $1330 \mathrm{keV}$. Again, due to the penetration abilities of the high energy photons, a big difference is observed between $356 \mathrm{keV}$ and $1330 \mathrm{keV}$. Transmission increases with the increase of photon energy. At the photon energies of 356 and $1330 \mathrm{keV}$ the transmission values of $5 \mathrm{~cm}$ thick TMZ10 glass are 0.0433 and 0.281 respectively. Fig. 3 also shows that, among the simulated glasses, the lowest transmissions for all photon energies occur for the TMZ10 sample and highest transmissions occur for the TMZ30 sample. This behaviour is due to the higher fraction of TeO2 existed in TMZ10 glass and the atomic number of Te $(Z=52)$ is higher than the atomic number of Mo $(Z$ = 42). Since the decrease in the Te content in TMZ30 is compensated by the increase in Mo atoms, the transmission values for all glasses are close to each other at the selected energies. Furthermore, for the photon energies starting from $1100 \mathrm{keV}$, pair production is the dominating photon interaction mechanism and above this energy interaction mechanism becomes almost independent of chemical structure.

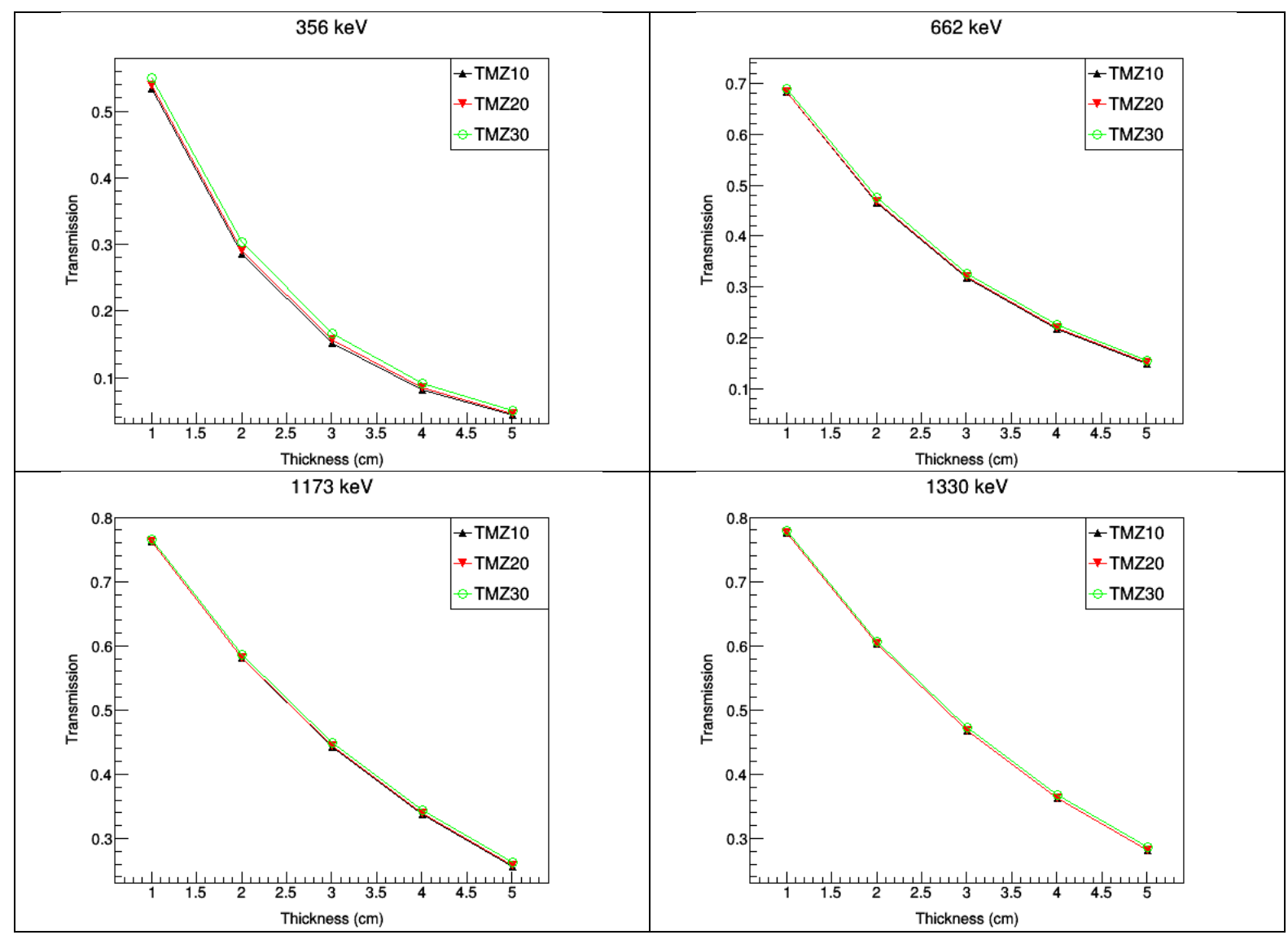

Figure 3. Transmission factor versus the thickness of $\mathrm{TeO}_{2}-\mathrm{MoO}_{3}-\mathrm{ZnO}$ (TMZ) glass system at 356, 662, 1173 and 1330 $\mathrm{keV}$ photon energies. 
The two important parameters characterizing the shielding ability of the TMZ glass system are the mean free path (MFP) and the half value layer (HVL) of the glass system. It is important to mention here that the lesser the value of MFP and HVL of given material, the better the shielding properties it would possess and thanks to the lower value of MFP and HVL, better shielding performance can be obtained by using a thinner layer of the selected material. Fig. 5 and Fig. 6 show the plot of MFP and HVL values of the $\mathrm{TeO}_{2}-\mathrm{MoO}_{3}-\mathrm{ZnO}$ glass system versus the photon energies. As can be seen from these two plots, TMZ10 has the lowest and TMZ30 has the highest values of MFP and HVL at the given photon energies. Depending on the close atomic numbers of Te and Mo elements, the observed differences for the MFP and HVL values are around $5.3 \%$ at $356 \mathrm{keV}$ and $1.6 \%$ at $1330 \mathrm{keV}$ for the $10 \%$ and $30 \% \mathrm{MoO}_{3}$ concentrations respectively.

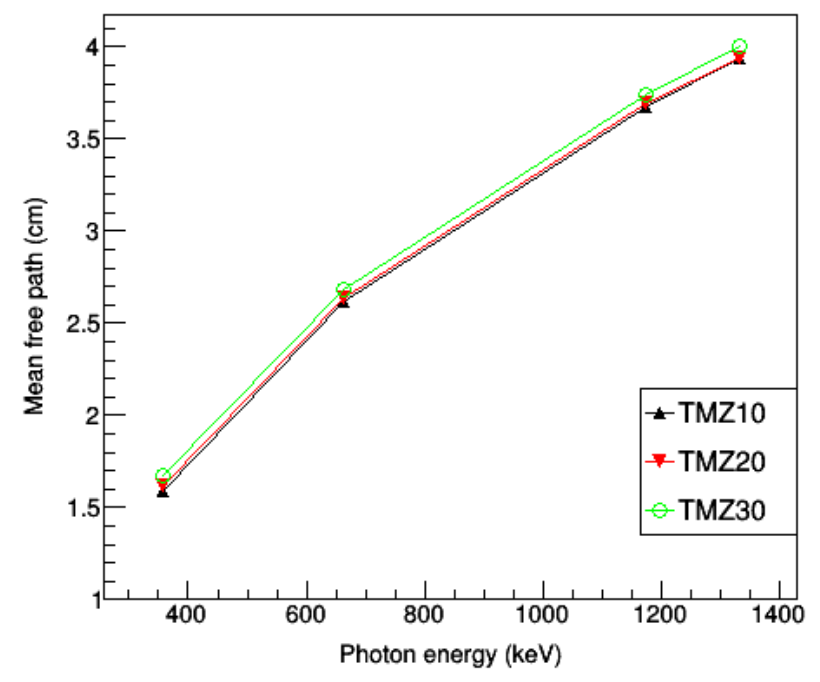

Figure 4. Mean free path of the $\mathrm{TeO}_{2}-\mathrm{MoO}_{3}-\mathrm{ZnO}$ glass system as a function of photon energy.

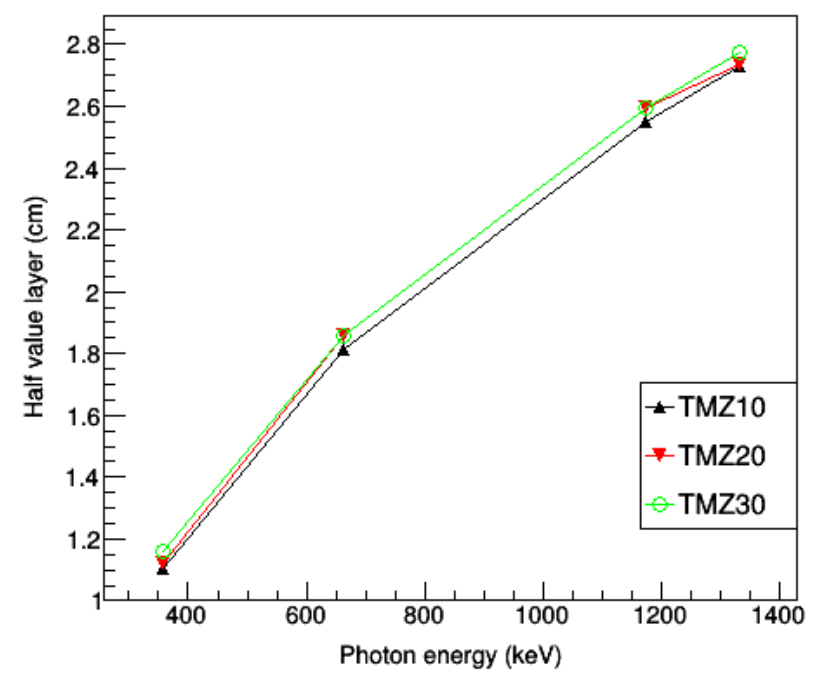

Figure 5. Half value layer of the $\mathrm{TeO}_{2}-\mathrm{MoO}_{3}-\mathrm{ZnO}$ glass system as a function of photon energy. 
In order to see the dependence of the mass attenuation coefficient and half value layer on the fraction of $\mathrm{MoO}_{3}$ existed in the selected glasses, these parameters were plotted versus the 10\%, 20\% and 30\% mol of $\mathrm{MoO}_{3}$ and the dependencies were shown in Fig. 6 and Fig. 7 respectively. For $10 \%$ and 30\% mol of $\mathrm{MoO}_{3}$, the mass attenuation values change from 0.120 to 0.125 at $356 \mathrm{keV}$ and from 0.0487 to 0.0497 at $1330 \mathrm{keV}$ respectively. In the same way, the half value layers change from 1.104 to 1.162 at $356 \mathrm{keV}$ and from 2.732 to 2.775 at $1330 \mathrm{keV}$. These findings also support that the decrease occurred for Te atoms are partially compensated by the increase in the Mo atoms in the glass structure. Therefore, mass attenuation values for the minimum and maximum $\mathrm{MoO}_{3}$ concentrations do not show a significant change.

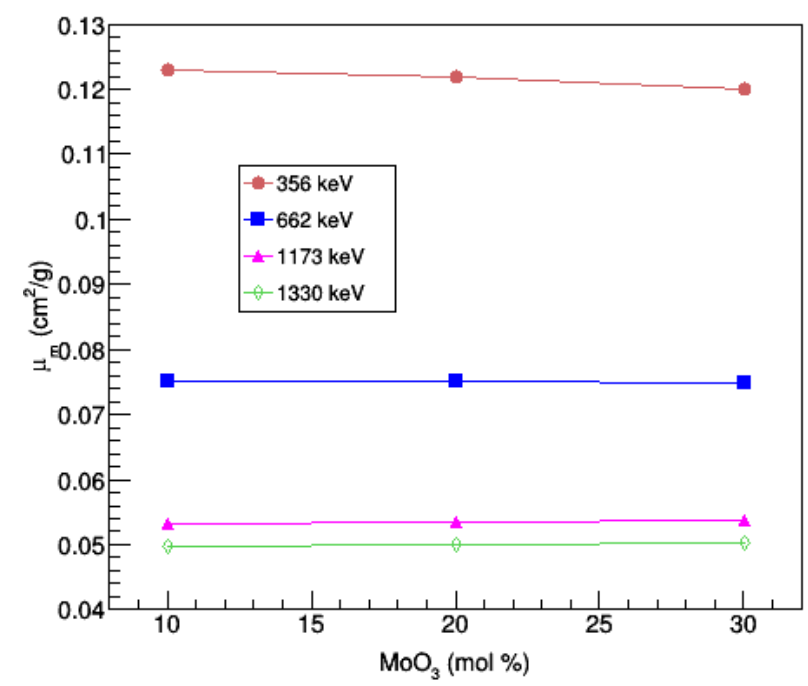

Figure 6. Dependence of mass attenuation values on the $\mathrm{MoO}_{3}$ amount in the glasses

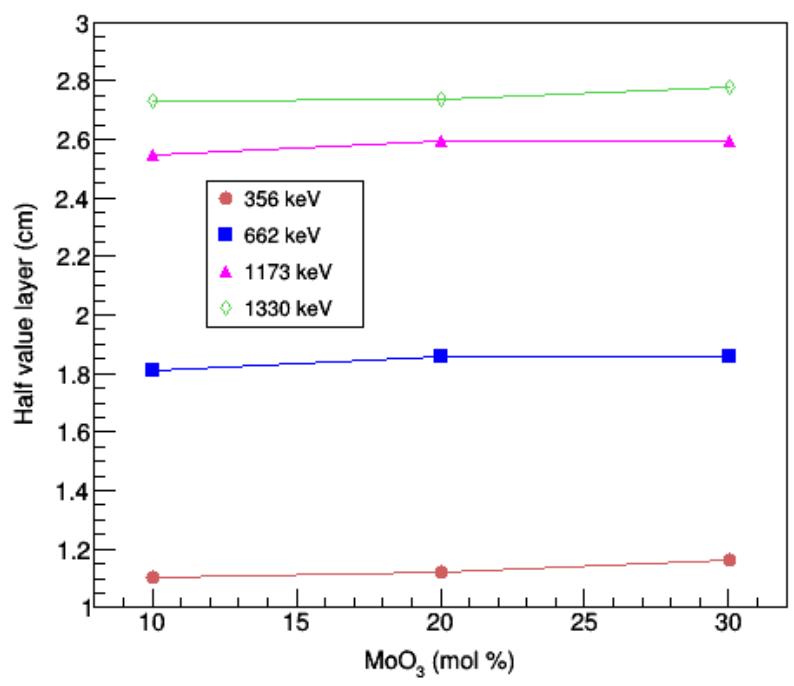

Figure 7. Dependence of half value layer on the $\mathrm{MoO}_{3}$ amount in the glasses 


\section{CONCLUSION}

In this study the photon shielding parameters of $(90-\mathrm{x}) \mathrm{TeO}_{2}-\mathrm{xMoO}_{3}-10 \mathrm{ZnO}$ glass ternary $(\mathrm{x}=$ $10,20,30 \mathrm{~mol} \%$ ) was investigated computationally using Geant 4 and WinXCOM database software to exploit the shielding potential of the selected glass system. Monte Carlo outputs of the Geant 4 have been analyzed and the following conclusions were arrived;

- Geant4 model of HPGe detector can be a reliable alternative to the experimental techniques especially in the absence of equipments or material samples to determine the shielding capability of any other materials.

- Mass attenuation coefficients determined using Geant4 and WinXCOM agrees well. Mass attenuation values are high at lower energy region and they decrease as the photon energy increases and stay almost unchanged at the energy region above $1100 \mathrm{keV}$. This trend observed in mass attenuation coefficients can be explained by the photon interaction mechanisms at low, medium and high energy regions in terms of photoelectric effect, Compton scattering or pair production respectively.

- Thanks to the function obtained from the best fit applied to the simulated data, mass attenuation values at any desired energy can be calculated.

- Increase of the $\mathrm{MoO}_{3}$ fraction from $10 \%$ to $30 \%$ in the glass structure causes an increase in the transmission fraction, half value layer and mean free path of the selected glass system and therefore weakens the shielding ability.

\section{REFERENCES}

[1] Gokce H.S., Ozturk B.C., Cam N.F., Cakir O.A., Gamma-ray attenuation coefficients and transmission thickness of high consistency heavyweight concrete containing mineral admixture, Cem \& Concr. Comp. 92 (2018) 56-69.

[2] Akkas A., Tugrul A.B., Addemir A.O., Marsoglu M., Radiation shielding effect of boron carbide aluminum metal matrix composite, Acta Physica Polonica A. 127 (2015) 947-949.

[3] Kurudirek M., Heavy metal borate glasses: potential use for radiation shielding, J. Alloy. Compd. 727 (2017) 1227-1236.

[4] Sharaf J.M., Hamideen M.S., Photon attenuation coefficients and shielding effects of jordanian building materials, Ann. Nucl. Energy. 62 (2013) 50-56.

[5] Olukotun S.F., Gbenu S.T., Ibitye F.I., Oladejo O.F., Shittu H.O., Fasasi M.K., Balogun F.A., Investigation of gamma radiation shielding capability of two clay materials. Nucl. Eng. Technol. 50 (2018) 957-962.

[6] Singh V.P., Shirmardi S.P., Medhat M.E., Badiger N.M., Determination of mass attenuation coefficient for some polymers using monte carlo simulation, Vacuum. 119 (2015) 284-288

[7] Singh V.P., Medhat M.E., Shirmardi S.P., Comparative studies on shielding properties of some steel alloys using geant4, mcnp, WinXCOM and experimental results, Rad. Phys. Chem. 106 (2015) 255-260.

[8] J. Singh, H. Singh, J. Sharma, T. Singh, P.S. Singh, Fusible alloys: a potential candidate for gamma rays shield design, Prog. Nucl. Energy. 106 (2018) 387-395.

[9] Kumar, A., Kaur, R., Sayyed, M.I., Rashad, M., Singh, M., Ali, A.M., 2019. Physical, structural, optical and gamma ray shielding behavior of $(20+x) \mathrm{PbO}-10 \mathrm{BaO}-10-\mathrm{Na}_{2} \mathrm{O}-$ $10 \mathrm{MgO}-(50-\mathrm{x}) \mathrm{B}_{2} \mathrm{O}_{3}$ glasses, Physica B Condens. Matter. 552 (2019) 110-118.

[10] Bagheria R., Moghaddam A.K., Shirmardi B. Azadbakht S.P., Saleh M., Determination of gamma-ray shielding properties for silicate glasses containing $\mathrm{Bi}_{2} \mathrm{O}_{3}, \mathrm{PbO}$, and $\mathrm{BaO}, \mathrm{J}$. Non-Cryst. Solids. 479 (2018) 62-71.

[11] Tijani S.A., Kamal S.M., Al-Hadeethi Y., Arib M., Hussein M.A., Wageh S., Dim L.A., Radiation shielding properties of transparent erbium zinc tellurite glass system determined 
at medical diagnostic energies, J. Alloy. Compd. 741 (2018) 293-299.

[12] Kumar A., Gamma ray shielding properties of $\mathrm{PbO}-\mathrm{Li}_{2} \mathrm{O}-\mathrm{B}_{2} \mathrm{O}_{3}$ glasses, Radiat. Phys. Chem. 136 (2107) 50-53.

[13] Kaewjaeng S., Kothan S., Chanthima N., Kim H., Kaewkhao J., Gamma radiation shielding materials of lanthanum calcium silicoborate glasses, Materials Today: Proceedings. 5 (2018) 14901-14906.

[14] Dogra M., Sinh K.J., Kaur K., Anand V., Kaur P., Singh P., Bajwa B.S., Investigation of gamma ray shielding, structural and dissolution rate properties of $\mathrm{Bi} 2 \mathrm{O} 3-\mathrm{BaO}-$ B2O3-Na2O glass system, Radiat. Phys. Chem. 144 (2018) 171-179.

[15] Dong M.G., El-Mallawany R., Sayyed M.I., Tekin H.O., Shielding properties of 80TeO25TiO2-(15-x)WO3-xAnOm glasses using WinXCOM and menp5 code. Radiat. Phys. Chem. 141 (2017) 172-178.

[16] Sayyed M.I., Lakshminarayana G., Dong M.G., Ersundu M.C., Ersundu A.E., I.V. Kityk, Investigation on gamma and neutron radiation shielding parameters for Bao/SroBi2O3-B2O3 glasses. Radiat. Phys. Chem. 145 (2018) 26-33.

[17] Agostinelli S., Allison J., Amako K., Apostolakis J., Araujo H., et al., 2003. Geant4-a simulation toolkit, Nucl. Instr. Meth. Phys. A 506 (2003) 250-303.

[18] Liu J.L., Wang W.C., Xiao Y.B., Huang S.J., Mao L.Y., Zhang Q.Y., $\mathrm{Nd}^{3+}$-doped $\mathrm{TeO}_{2}-$ $\mathrm{MoO}_{3}-\mathrm{ZnO}$ tellurite glass for a diode-pump $1.06 \mu \mathrm{m}$ laser, J. Non-Cryst. Solids. 506 (2019) 32-38.

[19] Gerward L., Guilbert N., Jensen K.B., Lerying H., WinXCom - A program for calculating Xray attenuation coefficients, Radiat. Phys. Chem. 71 (2004) 653-654.

[20] Sayyed M. I., Kaky K. M., Gaikwad D. K., Agar O., Gawai U. P., Baki S. O., Physical, structural, optical and gamma radiation shielding properties of borate glasses containing heavy metals ( $\mathrm{Bi} 2 \mathrm{O} 3 / \mathrm{MoO} 3)$, J. Non-Crystalline Solids, 507, 30-37 (2019) 